\title{
Green Policy Awareness and Secondary School Teachers' Perception of Interdisciplinary Approach to Teaching Environmental Education in Cross River State, Nigeria
}

\author{
E. E. Egbonyi ${ }^{1}$, D. B. Enu ${ }^{2}$, A. C. Omoogun ${ }^{1 *}$
}

\begin{abstract}
${ }^{1}$ Department of Environmental Education, Faculty of Education, University of Calabar, Calabar, NIGERIA ${ }^{2}$ Department of Social Science Education, Faculty of Education, University of Calabar, Calabar, NIGERIA

*Corresponding Author: omoogun.ajayi@yahoo.com
\end{abstract}

Citation: Egbonyi, E. E., Enu, D. B., \& Omoogun, A. C. (2020). Green Policy Awareness and Secondary School Teachers' Perception of Interdisciplinary Approach to Teaching Environmental Education in Cross River State, Nigeria. Interdisciplinary Journal of Environmental and Science Education, 16(1), e02203. https://doi.org/10.29333/ijese/6288

\section{ARTICLE INFO}

Received: 5 Nov. 2019

Revised: 11 Nov. 2019

Accepted: 11 Nov. 2019

\begin{abstract}
This study analyzed green policy awareness and secondary school teachers' perception of interdisciplinary approach to the teaching of Environmental Education in Cross River State, Nigeria. The study was guided by a research question which was transformed into a research hypothesis. The survey research design was used in the study. The population of the study consisted of the total number of teachers in Cross River State public secondary schools as at 2017 which was put at 5,194. A sample of 1030 respondents were used for the study a0nd a structured questionnaire was used to gather data which was analyzed with a simple linear regression analysis. The study found out that, teachers green policy awareness significantly predicted their perception of interdisciplinary approach to the teaching of Environmental Education. It was therefore recommended that, teachers should be proactive and diligent in teaching Environmental Education through their traditional teaching subjects. Moreso, since they are aware that environmental issues are imbeded in the school curriculum, it should be infused in their traditional teaching subjects.
\end{abstract}

Keywords: green policy, teachers perception, interdisciplinary approach, environmental education

\section{INTRODUCTION}

A policy is a principle of behavior or a conduct that is thought to be desirable, important, vital or necessary, especially as formally expressed by a government or any other body of authority.

Green policy therefore implies principles of behavior or necessary conduct expected of people in a given geographical domain to make the environment remain green. A green environment is a sustainable environment. Therefore, green policy is a policy that will make the environment sustainable. This means that environmental resources will be wisely used by the present generation without compromising its use by the future generation.

Nigeria is committed to the national policy on sustainable development based on proper management of the environment in order to meet the needs of the present and future generations (FRN, 1989). This commitment demands positive and realistic educational planning that balances human needs against the potentials of the environment.
However, the need for Environmental Education was first recognized by the international community at the United Nations Conference on the Human Environment in Stockholm, 1972 (Anijah-obi, 2001). The conference drew world attention to international ecological problems such as pollution, deforestation, loss of biodiversity, poverty, erosion, flood hazards, drought, desertification, urbanization, industrialization, over population, human and environmental health, endangerment and extinction of wildlife and sustainable development.

In the declaration of the above conference, it was observed that, it has become imperative for mankind to defend and improve the environment for present and future generation. The conference therefore recommended thus:

Concerned international agencies should after consultation and agreement, take the necessary steps to establish an international programme in environmental education, interdisciplinary in approach, in school and out of school, encompassing all levels of education and directed towards the general public .... With a view to educating the public in simple 
steps it must take, within its means to manage and control its environment (World Development Report, 1992).

Following the above recommendation, the United Nations Educational, Scientific and Cultural Organization (UNESCO) and the United Nations Environmental Programme (UNEP) initiated international Environmental Education programme to promote Environmental Education. This gave rise to the organization of the "Belgrade workshop" which originated the Belgrade Charter that provided the guidelines for Environmental Education. This worldwide cooperative effort was further consolidated by regional conference of experts on Environmental Education in Africa (Brazzaile, 1976; Lagos, 1976) among others (Inyang-Abia \& Umoren, 1995).

Accordingly, an inter-governmental conference on Environmental Education was held in Tbilisi in 1977, “The Tbilisi conference clearly stressed that since Environmental Education was a new perspective in existing curricula, it should be included as a component in all existing programmes and courses to reflect adequately all the environmental concerns of contemporary society as appropriate to the content and methodology of such system" (Inyang-Abia and Umoren, 1995). The decision to include Environmental Education in the educational curricula is referred to as the Green policy. Inyang-Abia (1997), Omoogun (1997) and Obi (1997) made reference to the inclusion of Environmental Education components in the school curriculum as greening the curriculum.

Martin (2007) also observed that, there has been a growth in awareness about the changes to the curriculum for sustainable development and opined that, these changes must suffuse all areas of education provision. Adding that it cannot be restricted to environmental disciplines or ecoliteracy modules or even to the classroom but must be demonstrated by the higher education institutions approaches and practices. According to Martin (2007) barriers to suffusing green curriculum may mean that changes in HEIs will have to be driven by external processes such as the transformation of primary and secondary education, where the fragmentation of knowledge is less entrenched, adding further that, there now seems to be growing agreement that HEIs should equip all their students with environmental literacy and that sustainability should be central to concerns, both in HEIs curriculum and in operational practices including the use of interdisciplinary approach.

Moreso and Devi (2007) reported that, the basic premise of an interdisciplinary education is that, "just as there is a wholeness and interdependence to life in all its forms, so must there be a unity and wholeness to efforts to understand it and ensure its continuation" that this calls for both interdisciplinary inquiring and action. It does not, of course, imply an end to work within traditional disciplines. But a disciplinary focus is often helpful and even necessary in allowing the depth of inquiring needed for major breakthrough and discoveries especially in Environmental Education (Devi, 2007).

The interdisciplinary approach to the teaching of Environmental Education involves, the interdisciplinary Teacher cooperation which according to Huiying, (2015) embodied the views of Environmental Education for sustainability. Its methods according to Huiying (2015) include integrating holistic character, with emphasis on interdisciplinary teacher cooperation in which the teacher guides students to find and resolve environmental issues by cooperation of aesthetic, social, economic, political, historical and cultural disciplines.

Based on the above premise the Nigerian Educational Research and Development Council (NERDC) has developed a national Environmental Education curriculum. The philosophy of this curriculum is derived mainly from the National Policy on Education, which specified producing people, or citizenry who can apply knowledge to the improvement and solution of environmental problems for the use and conveniences of man. The Environmental Education curriculum is structured to be taught in the secondary schools through the traditional teaching subjects approach (NERDC, 1997).

The curriculum has three major objectives for all categories of learners within the formal and non-formal sectors of the educational systems.

These objectives are:

1) Acquiring knowledge and understanding of, and sensitivity to the total environment and its allied problems and humanity's critical response, presence and role in it.

2) Developing skills in investigating and evaluating ecological, political, economic, social, aesthetic and educational factors for solving environmental problems.

3) Developing attitudes, values and strong feelings of concern for the environment and the motivation for actively participating in its protection and improvement.

To achieve these objectives, the curriculum is structured into four themes according to Anijah - Obi (2001) the themes are:

1) Ecological foundation

2) Human environment and development

3) Environmental change and impact

4) Sustainable development

The approach allows for objectives within a theme to be infused into existing school subjects at the primary and secondary schools. Relevant topics and issues within each theme are therefore structured into performance objectives, content, learning activities, teaching materials and evaluation guidelines. To aid the implementation of the curriculum, the institutional and school responsibilities according to AnijahObi (2001) are:

1) Adopting an environmental education policy

2) Providing the opportunity for staff development

3) Evaluating environmental education along with core subjects.

While teachers responsibilities include;

1) Incorporating Environmental Education objectives and strategies into existing subjects and programmes as appropriate.

2) Developing students' values and skills through values clarification and analysis, group dynamics and decision 
making and encouraging participation by involving students in first-hard experiences.

But the way Environmental Education Skills are taught in our secondary schools, especially in Cross River State leaves much to be desired. Many teachers may not have understood the green policy and the interdisciplinary approach to teaching Environmental Education. This may be due to the fact that individual teachers perception of the green policy differs. This study is focused on developing among teachers in Cross River State awareness of Green Policy through Interdisciplinary Approach to the teaching of Environmental Education.

\section{Statement of the Problem}

Environmental Education is still a new comer in Nigerian educational system. This is seen in the fewness of Universities in Nigeria that offers Environmental Education courses. This limitation is further compounded by the fact that Environmental Education curriculum is based on the UNDP recommendation of teaching Environmental Education through interdisciplinary (infusion) or multidisciplinary approach especially in the primary and secondary schools.

In view of the need for Environmental Education, only few teachers in the Secondary Schools have higher degrees in Environmental Education as a discipline, while most secondary school teachers have their traditional teaching subjects where Environmental Education is infused.

Moreso, it is worrisome that the environmental activities such as, conservation clubs, excursion and field trips that existed in secondary schools are no more practiced. Students and teachers no longer pay attention to environmental awareness creation. The teaching of Environmental Education in secondary schools is gradually declining and its status is uncertain. The concern of the researchers is therefore to investigate the influence of green policy awareness and teachers perception of the interdisciplinary approach to the teaching of Environmental Education because the status of environment education in secondary schools in Cross River State is uncertain.

It is on this premises that, this study aimed at investigating the level of secondary schools teachers' green policy awareness and their perception of the Interdisciplinary Approach to the teaching of environmental education in the secondary schools in Cross River State, Nigeria.

\section{Research Question}

To guide the study, a research question was formulated thus;

How does Cross River State teachers' green policy awareness influence their perception of the interdisciplinary approach to the teaching of Environmental Education?

\section{Statement of Hypothesis}

The research question was therefore transformed into a hypothesis stated thus:

The influence of Cross River State teachers' green policy awareness on their perception of interdisciplinary approach to the teaching of environmental education is not significant.

\section{METHODOLOGY}

The survey research design was used for this study. The design was considered appropriate for the study because it is concerned with critical examination of the features of the whole population through a chosen sample. The design also permits inference and generalization to the whole population from a study of a representative sample of the population.

\section{Population of the Study}

The population of the study is the total number of teachers in Cross River State public secondary school which is 5,194 as at the 2016/2017 academic year, (CRSSEB, 2017).

\section{Sampling Technique}

The stratified random sampling technique and the simple random sampling technique were used. The study area, Cross River State is educationally divided into three Zones for ease of administration by Cross River State Government via Cross River state Ministry of Education. The Education zones are: Calabar Education Zone with Seven Local Government Areas has a total of seventy five (75) public secondary schools under it. Ikom Education Zone with six (6) Local Government Areas has a total of ninety three (93) public secondary schools under it, and Ogoja Education Zone with five (5) local government areas has a total of seventy one (71) public secondary schools. This makes a total of 239 public secondary schools in Cross River State.

The number of Teachers in each of the education zone are as follows: Calabar Education Zone, 2062 Teachers, Ikom education zone, 1,724 teachers and Ogoja Education Zone, 1,408 teachers. This makes a total of 5,194 teachers in Cross River State public secondary schools. Using the stratified random sampling, the researchers adopted for use $20 \%$ of schools in each of the education zones. Therefore $20 \%$ of 75 public schools in Calabar education zone is $15,20 \%$ of the 93 public secondary schools in Ikom education zone is 18.6 approximately 19 and $20 \%$ of the 71 public secondary schools in Ogoja education zone is 14.2 approximately 14 . This makes a total of 48 public secondary schools for the study.

However, the 48 public secondary schools were selected by simple random sampling technique. Using the stratified random sampling technique, 42 respondents were drawn from Calabar Education Zone, 345 from Ikom education zone and 281 respondents from Ogoja education zone to give a total of 1038 teachers.

\section{Sample}

A sample of 1030 , which is $20 \%$ of the total population, was used for the study. These 1030 Teachers were drawn from the 48 sampled public secondary schools in Cross River State.

\section{Instrumentation}

The research instrument used was a structured questionnaire titled "questionnaire on green policy awareness and secondary school teacher's perception of interdisciplinary approach to teaching Environmental Education" (QGPASSTPIATEE). This instrument contained 18 items divided into two sections. Section one on green policy awareness has nine items. Section two on perception of 
Table 1. Simple Linear Regression Analysis of the influence of Teachers' Green Policy Awareness on their Perception of Interdisciplinary Approach to the teaching of Environmental Education in Cross River State

\begin{tabular}{|c|c|c|c|c|c|c|c|}
\hline \multicolumn{3}{|c|}{ Variables } & $\mathbf{N}$ & Mean & SD & $\mathbf{r}$ & P.level \\
\hline \multicolumn{3}{|c|}{$\begin{array}{l}\text { Perception of interdisciplinary approach to Env. Education } \\
\text { Green policy awareness }\end{array}$} & $\begin{array}{l}1.30 \\
1.30\end{array}$ & 19.8311 .58 & $\begin{array}{l}5.18 \\
3.54\end{array}$ & .965 & .000 \\
\hline Model & SS & Df & & Ms & F.ratio & & P.level \\
\hline \multirow[t]{2}{*}{ Regression } & 25738.442 & 1 & & 25738.442 & & & \\
\hline & & & & & 13998.285 & & .000 \\
\hline Residual & 1890.169 & 1028 & & 1.839 & & & \\
\hline Total & 27628.611 & 1029 & & & & & \\
\hline
\end{tabular}

*significant at $\mathrm{p} .05, \mathrm{r}=.965$, Adj. $\mathrm{R}=.932$

interdisciplinary approach to the teaching of Environmental Education has nine items. It is a four point Likert scale of Strongly agreed (SA), Agreed (A), Disagreed (D) and Strongly disagreed (SD) that was coded 4,3,2 and 1 for positively worded statements and 1,2,3 and 4 for negatively worded statements respectively. Data collected from respondents were analyzed using simple linear regression.

\section{RESULTS/FINDINGS}

The result of the study was shown in Table 1 .

From the hypothesis stated, the independent variable was Teachers Green Policy Awareness while the dependent variable was Teachers Perception of Interdisciplinary Approach to the teaching of Environmental Education. The result as presented in Table 1 indicated that there was a positive significant influence of green policy awareness of Teachers on their perception of interdisciplinary approach to the teaching of Environmental Education in the secondary schools $(\mathrm{r}=.965, \mathrm{P}<.05$ at $\mathrm{df}=1028)$. The regression analysis showed that the Teachers Green Policy Awareness significantly predicted their perception of interdisciplinary approach to the teaching of Environmental Education in the secondary school $(\mathrm{F}=13998.285, \mathrm{P}<.05)$. In other words, the Teachers Perception of Interdisciplinary Approach to the teaching of Environmental Education is significantly influenced by their green policy awareness.

Again, the green policy awareness accounted for about $52.22 \%$ (Adjusted $\mathrm{R}=.932$ ) of the factors influencing interdisciplinary approach to the teaching of Environmental Education. This therefore means that the null hypothesis earlier stated was rejected. This finding is in harmony with Huiying (2015) that, soiling teachers cognition is premised on carrying out the interdisciplinary Teacher cooperation. Adding that participant's motivation influences their passion of participating in the interdisciplinary Teacher cooperation. Noting further that, Teachers participants motivation that would trigger their perception were mainly influenced by the fact that Teachers are not clear why Teachers of different disciplines should cooperate in teaching of Environmental Education. The finding is also in line with Lydia (2011) who reported that in Tanzania, primary school Teachers expressed variations in their perceptions of Environmental Education and Education for Sustainable Development because Teachers claimed that the approach used to integrate Environmental Education in the school curriculum was not favourable and that what is to be taught as environmental green policy is necessary and as a pre-requisite to the proper teaching of Environmental Education in schools.

\section{CONCLUSION AND RECOMMENDATION}

The study examined green policy awareness and secondary school Teachers perception of interdisciplinary approach to the teaching of Environmental Education in Cross River State, Nigeria. Data collected and analyzed shows that there was a positive significant influence of green policy awareness of Teachers on their perception of interdisciplinary approach to the teaching of Environmental Education in secondary schools. The regression analysis showed that the Teachers green policy awareness significantly predicted their perception of interdisciplinary approach to the teaching of Environmental Education. This also means that green policy awareness influence the Teachers perception of interdisciplinary approach to the teaching of Environmental Education at the secondary schools level. This is apt, in the sense that green policy implies that environmental issues are incorporated in the secondary school curriculum, and interdisciplinary approach of teaching Environmental Education involves the infusion of Environmental Education topics in their traditional teaching subjects. Teachers' awareness of this challenging curriculum will therefore enhance their perception of the interdisciplinary approach of the in structured delivery of those topics through their traditional teaching subjects.

The Study recommends that Teachers should be proactive and diligent in teaching Environmental Education by strengthening their traditional teaching subjects since environmental issues are imbedded already in the school curriculum and should be infused in their traditional teaching subjects.

\section{REFERENCES}

Anijah-Obi, F. N. (2001). Fundamentals of Environmental Education and management. Nigeria: University of Calabar press.

Cross River State Secondary Education Board. (2017). Teachers statistics.

Devi's (2007). An Interdisciplinary Approach to learning. Retrieved from https://www.deccanherald.com 
Federal Republic of Nigeria FRN. (1989). Nigeria policy on the Environment. Abuja: Federal Environmental Protection Agency.

Huiying, X. (2015). Interdisciplinary approach to environmental education. Two case study in china. Centre for global integrated education.

Inyang-Abia, M. E. (1997). Input evaluation of greenness, tools and strategies of Junior secondary social studies curriculum in Nigeria. West Africa Journal of Education Research, 84-88.

Inyang-Abia, M. E., \& Umoren, G. U. (1995). Curriculum development and evaluation in Environmental Education. Ibadan: Macmillan Nigeria publishers Limited.

Lydia, A. K. (2011). Integrating Environmental Education in primary school education in Tanzania: Teachers perceptions and teaching practices. Finland: Abo Akademio Forlag-Abo Akademi university press.
Martin, H. (2007). Greening the University Curriculum: Appraising an International Movement. Journal of Geography in Higher Education, 29(1), 31-48. https://doi.org/10.1080/03098260500030355

Obi, F. B. (1997). Greening the school curriculum: the role of the teachers. West Africa Journal of Educational Research, 93-96.

Omoogun, A. C. (1997). The perpetuating variables of environmental crises: the peasant example and some implications for Environmental Education. West Africa Journal of Educational Research, 199-202.

World Development Report (1992). Development and the Environment. World Bank: Oxford University Press. 